\title{
The Order of the Art
}

\author{
Iwona Grodź \\ Adam Mickiewicz University, Poznań, Poland
}

\begin{abstract}
The theme of the article is Polish movie Illumination directed by Krzysztof Zanussi to his own screenplay in 1972 (cinema premiere 1973). "The film contains elements of Zanussi's intellectual biography as well as documentary elements, e.g., appearances of philosopher Władysław Tatarkiewicz". It is one of the most important Polish films. The purpose of the text is to examine the philosophical contexts in this film, and the relationship between "orders", "art", and "science". The research method is: semiotics, psychology of perception and comparative research. The text will refer to the philosophical writings: Blaise Pascala's Thoughts, St. Augustine's Confessions and the monograph work of Krzysztof Zanussi, for example, Mariola Marczak's Anxiety and Longing, Movies and the Value, About the Films of Krzysztof Zanussi (Publisher: University of Warmia and Mazury in Olsztyn, 2011) or Tomasza Kłysa, The Intellectual Cinema of Krzysztof Zanussi, in "Bulletin de la Société des Sciences et des Lettres de Łódź" (vol. XLV); Série: "Recherches sur les Arts" (vol. VI); Polish Cinema in Ten Takes, edited by E. Nurczyńska-Fidelska, Z. Batko (Publisher: Lodz Scientific Society in Lodz, 1995).
\end{abstract}

Keywords: Polish film, "cinema of moral anxiety”, synergy of the art and the science, Krzysztof Zanussi

\section{Introduction}

"Elitism of the spirit", it is a phrase, which refers the recipient to at least two meanings. One is associated with the realm of thought. Therefore, the philosophical context is the most appropriate for it. The other meaning clearly indicates a historical context which, when combined with the ethos of aristocratic elitism, points to the realm of art and science. The combination of those two meanings allows us to uncover the metaphorical meaning of the juxtaposition: "elitism of the spirit" - clearly referring to the intellect, emotions, sense of beauty, and thus to broadly understand spiritual life.

Iluminacja (Illumination), a film by Krzysztof Zanussi (1972), ${ }^{1}$ undoubtedly fits into this line of interpretation. What is more, we can quite precisely establish three orders that constitute the above-mentioned "spiritual elitism", which is often mentioned in the context of the director's works. It is the order of science (orde du ratio), the order of art (orde du ars), and the order of the heart (orde du coeur). Their analysis makes it possible to interpret differently each time the "illumination" from the title, i.e., the significance of the film. Moreover, it points out to a very precise composition concept which is based on constant intermingling of images belonging to those three domains. At the same time, it quite clearly indicates, paradoxically, the double road travelled by the main protagonist, the road of change and invariability. The change consists in Franciszek Retman (Stanisław Latałło) passing from the realm of science: the first scene in which we observe the

Iwona Grodź, Doctor, Lecturer, Faculty of Polish and Classical Philology (Institute of Polish Philology, Department of Film, Television and New Media), Adam Mickiewicz University.

${ }^{1}$ See on-line: http://culture.pl/en/work/the-illumination-krzysztof-zanussi. 
corporeality of the main protagonist, to the sphere of life; the last scene, in which the protagonist stands in a river, staring at the water flowing. On the other hand, the invariability of the situation is indicated by the loneliness of the protagonist and the way he is presented: a dark background of abstract space and the nature, but next to the family - the protagonist's inclination to thoughtfulness and the manner of his presentation, interest in him on the verge of adolescence and then adulthood. The framing device suggests a constant state of flux, i.e., changes taking place in the life of Franciszek Retman as well as the invariability of his attitude to life and the way the creator is interested in him. It is also worth considering in what aspects the three above-mentioned orders are visible in Iluminacja, and therefore, what impacts their analysis can have on the significance of the title. ${ }^{2}$

\section{Orde du Ratio}

"Whenever we find a fixed point to attach and fix ourselves to, it shifts and leaves us and, if we follow it, it slips away from us and flees from us eternally" (Blaise, 1953). ${ }^{3}$

The order of science clearly dominates in the first part of the film. In terms of the plot, it is associated with the protagonist undertaking studies at the faculty of mathematics and physics. We return to this realm when the protagonist decides to begin Ph.D. studies. "It is the young boy who is a representative of the youngest generation belonging to the realm of science: a university, a lecture hall, and a dormitory. We will learn his story in a series of quick shots, iconographic symbols, for example, a credit book-a symbol of youth, science", ${ }^{4}$ which tells us, for example, about his exceptional scientific abilities, the reasons why he undertook the studies, the joy at the news about passed exams, a farewell to his mother at the station, and the first month at the university. Based only on those brief images, we can draw a conclusion that we are dealing with a person who is thoughtful and shy, yet, youthfully spontaneous, a person who wants to learn something. His awkwardness is felt primarily during the exam. When asked about the reasons underlying his decision to study at this particular faculty, he answers generally, suggesting his wish to get closer to knowing the essence of things. Old professors, clearly distanced from the epistemic possibilities of science, are not able to follow his line of reasoning, i.e., share the naive faith in the existence of an answer to his questions. The interviewers find the boy's straightforwardness amusing, and it unexpectedly turns out to be the dominating feature of his personality. Stanisław Latałł, with an educational background in camerawork rather than acting, ${ }^{5}$ was consciously chosen as the main protagonist, which suggests that the director wanted to depict an authentic, sensitive person with a clear heart, i.e., someone who can be closer to the state of illumination or even epiphany.

To this realm belong also two quasi-documentary quotations, in which students or Ph.D. students older than him talk about the possibilities of science: inventing a nuclear bomb, the significant past of physics, its

\footnotetext{
${ }^{2}$ See Tomasz Kłys, Polifoniczność i naoczność idei: "Iluminacja” Krzysztofa Zanussiego (Polyphonicity and visibility of an idea: "Iluminacja" by Krzysztof Zanussi); Don Friedricksen, "Iluminacja” Krzysztofa Zanussiego: psychologiczna forma i duchowa diagnostyka ("Iluminacja" by Krzysztof Zanussi: psychological form and spiritual diagnostics), in Kino polskie: reinterpretacje. Historia-ideologia-polityka, Konrad Klejsa, Ewlina Nurczyńska-Fidelska (Eds.), Kraków 2008; Łukasz Plesnar, W poszukiwaniu absolutu. "Iluminacja” Krzysztof Zanussiego (In search of the absolute. "Iluminacja” by Krzysztof Zanussi), in Analiza i interpretacja. Film polski, Alicja Helman, Tadeusz Miczka (Eds.), Katowice 1984.

3 Blaise Pascal (2004), Thoughts, translated by T. Żeleński (Boy), Warszawa:"Green Owl”.

${ }^{4}$ Cf. Krzysztof Zanussi, Iluminacja (Illumination) and Eksplikacja (Explication), "Kino” 1973, no. 5, pp. 25-30.

5 See a documentary film on the character: Ślad (Trace), directed by Marcin Latałło. Please note that Stanisław Latałło was killed during a mountaineering expedition a year after shooting Iluminacja, at the age of 29, i.e., exactly in the same year in which we part with Franciszek Rettych.
} 
present condition, and advantages following from working at the university ${ }^{6}$. "The photography by Edward Kosiński in this part of the film is sloppy on purpose: rough and shaky, it suggests the author's distance and his wanting to focus primarily on what the young people are saying". ${ }^{7}$ On the other hand, using this and not any other type of narration, where they want to say everything, forcefully and conclusively, the authors leave the viewers "out of breath" in a way. The language of the images is the softness of understatements, which are absorbed by perfectionism and - the often postulated-"emotional coldness" of film statements by Krzysztof Zanussi. Nonetheless, during the conversation, there are many opinions which will later be confirmed in the life of Franciszek himself. It is primarily about having doubts as to making any radical changes in this particular domain and the imperfection of scientific knowledge.

At the opposite pole, there are education-related quotations by well-know academics. They are very much lecture-like, they are set in rigid forms and they are a kind of a scientific interpretation of the film. Because of such manner of presentation, today they strike the viewer as anachronic and pompous. Although perhaps, paradoxically, they refer more to, or are characteristic of not so much the director's approach to the film substance, but rather the behaviour of scientists themselves. Having conducted a thorough analysis, it even seems that the decision to include, for example, professor Władysław Tatarkiewicz's comment on illumination was supposed to make the viewers realize the difference between the approach and lifestyle of mature academics and young students. ${ }^{8}$ The clash is crushing for both the groups: pompousness versus nonchalance, bigheadedness versus scientific immaturity, spectacularity versus simplicity and youthful spontaneity.

Including in the film two quasi-documentary discussions and several scientific monologues allows us to reflect upon the fictional fate of Franciszek, who also has scientific aspirations. His most significant statements are those in which he complains to his supervisor that he is unable to choose anything yet, because he has the feeling of being still at the start of education. Moreover, he is aware that the knowledge offered at the university is anachronic. By the same token, he shows both his doubts and the need to catch up on the learning fast. After the meeting, Zanussi - by quickly showing some images - reminded the viewers of the figures of renowned scientists, for example, Albert Einstein, who had been successful and had become famous scientists before they turned thirty. Being pressed for time and success sometimes turns out to be the main driving force behind the main protagonist's actions. He also holds an important talk with the university vice-chancellor, right before he suspends his studies for some time, and after returning to the university with a still open question about the possibilities of getting to know the essence of things by means of science (see Figure 1).

Questions concerning the purposefulness of pursuing scientific work are tackled by the director also in another plot. The main protagonist is forced to take care of his family, leave the university, and take up physical work. For example, he works at an oncological hospital, in which he meets an ill mathematician. He tells him that he decided to study physics because he was hoping that it was a science precise enough to make it possible for him to gain some concrete knowledge about mechanisms governing the reality. He is also wondering

\footnotetext{
6 "An unusual form: film essay, inspired by Thomas Mann's prose, ideally combines philosophical reflection over the essence of illumination and a scientific approach to the issue". Cf. Sławomir Bobowski, O eseju filmowy. Na przyktadzie "Iluminacji" Krzysztofa Zanussiego (On film essay. On the example of "Iluminacja” by Krzysztof Zanussi), in "Studia Filmoznawcze" X, Jan Trzynadlowski (Ed.), Wrocław 1991 and Sławomir Bobowski, Dyskurs filmowy Zanussiego (Zanussi's film discourse), Wrocław 1996.

${ }_{7}$ Ryszard Ciarka, Wiedza, wiara i nadzieja (Knowledge, faith and hope), in "Kwartalnik Filmowy” 1997, no. 18, p. 96.

8 The director also told what was deleted from the film: a comment by professor Aleksandrowicz on the fear of death; a report from a hypnosis session by Lech Emfazy Stawiński; a comment on material basis for memory transfer in animals (dr Velutani), materials from psychiatric hospitals, a yoga scene; information on the Möbius strip by professor Tomaszewski.
} 
whether studying biology would not be a good solution. During the conversation, the experienced mathematician in a way foresees the kind of illumination which is probably experienced by the protagonist at the end of the film. It is the awareness that there are no definite and clear answers, i.e., realizing the worthlessness and insignificance of reflecting upon issues which are never to be resolved. That is probably why the ill man chooses mathematics as a science which is more abstract, and as such more distanced from life and similar questions. He says: "You really think that the reality is so important as to be concerned with it?"

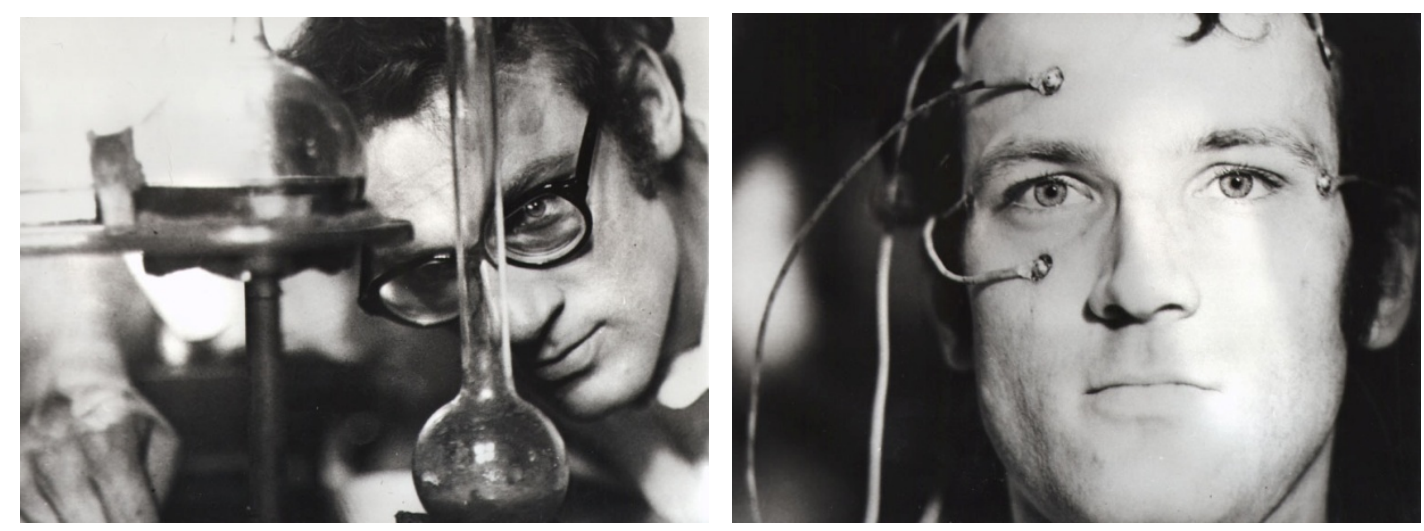

Figure 1. Photos from Iluminacja, directed by Krzysztof Zanussi.

The philosophy of life which the ill man represents brings to mind three films. One of them is the debut film by Krzysztof Zanussi entitled Struktura krysztatu (Crystal structure) (1969). ${ }^{9}$ The second and the third ones are highly original Polish animations: Schody (Stairs) and Wszystko jest liczbq (Everything is a number) by Stefan Schabenbeck. In the first case it is about an analogous reference to two approaches to life: one that is active, searching_vita activa (Marek from Struktura krysztalu or Franciszek from Iluminacja) and one that is passive, contemplative - vita contemplativa (Jan from Struktura krysztalu and the mathematician and monks from Iluminacja). An original combination of the two approaches to life is presented by Stefan Schabenbeck in an animated story entitled Schody, which is a kind of a metaphor of a person's journey through life. An anonymous figure, without any characteristic features, climbs many steps up the stairs only to become one of the steps once he/she reaches the goal. The metaphor is shocking with its simplicity and truth.

A puzzling issue is the literal and metaphorical meaning of the title of the second film by the same author, i.e., Wszystko jest liczbq. In the case of this picture, the metaphor is being "recycled" in a way, i.e., it is once again processed by making its meanings literal (the catechesis solution). One could ask questions: Was it not made banal in the process? What points to the fact? What follows from it? Making the meanings literal best corresponds to the idea of analysis and interpretation based on the ties between art and science. Following this line, one could point to the reference to op-art and psychology of perception of a visual image (constant emphasis of the ambiguity of the visual sign, a peculiar game: the content plane and the expression plane); to symbolism of infinity associated with the motif of the Möbius strip, the symbolism of numbers (reference to

\footnotetext{
${ }^{9}$ See e.g., Struktura pewnego debiutu. Rozmowa z Krzysztofem Zanussim (Structure of a certain debut. An interview with Krzysztof Zanussi), in Debiuty polskiego kina, Marek Hendrykowski (Eds.), Konin 1998; Bolesław Michałek, Struktura kryształu (Crystal structure), "Kino" 1969, no. 10; Krzysztof Kornacki, “W perspektywie wieczności...”. Metafizyczne $i$ religijne komponenty "Struktury krysztatu" Krzysztofa Zanussiego ("In the perspective of eternity...". Metaphysical and religious components of "Crystal structure” by Krzysztof Zanussi), in Krzysztof Kornacki, Kino polskie wobec katolicyzmu, Gdańsk 2004. Also see films: Śmierć prowincjała (The death of the provincial) (a religious plot) or Spirala (Spiral) (a mountain plot associated with the true story of Stanisław Latałła's death in the mountains, presented in the film Slad (Trace)).
} 
philosophy, e.g., Pythagoras, Gottfried Wilhelm Leibniz) or the idea of vanitas (see Figure 2). ${ }^{10}$
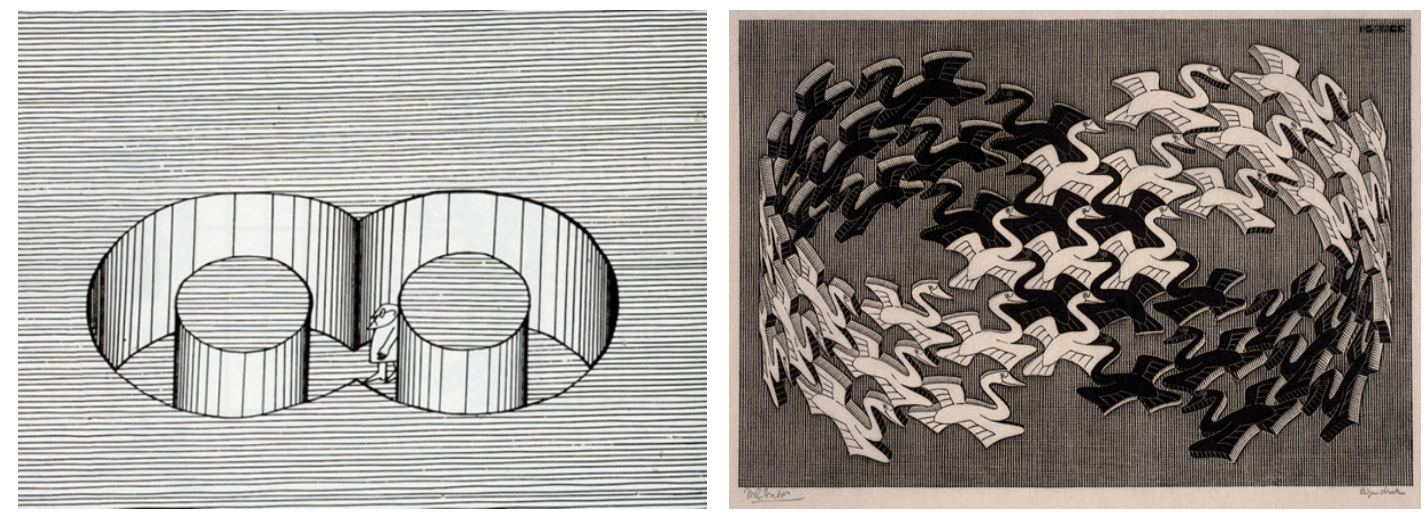

Figure 2. An image from the film Wszystko jest liczba dir. Stefan Schabenbeck (1966) and drawing Maurits Cornelius

Escher Labedzie /Swans (1956).

Schody and Wszystko jest liczba, therefore, pose a similar question about the purposefulness of the earthly existence. Zanussi seems to be saying that such a question cannot be answered by science, but by ordinary life. Nevertheless, the author of the animation is trying to subordinate life to art and science-however, his diagnosis is very sad.

Coming back to Iluminacja, the scenes taking place in the hospital are foreshadowed by a series of shots with images taken as if from anatomy atlases, in which we see an image of the human foetus or various genetic anomalies. Getting to know the human nature from the point of view of biology or medicine becomes the subject of talks between Franciszek and a doctor. The protagonists talk about the inability to clearly determine when a human being is still a human being and when they are no longer one. The doctor tells the boy about brain death, neurological surgeries, experiments on monkeys, spiders, etc. Zanussi, on the other hand, places in the film several documentary quotations by persons suffering from schizophrenia and other mental dysfunctions.

In this part of the film, editing plays a very important role. "It resembles a technique of intellectual editing (montage) by Siergei Eisenstein"11 or experiments by New Wave artists. Fast changing images, combined with one another often on the basis of a contrast. Owing to this, it is possible for the film creator to make the viewer emotionally involved and focussed. At another point, the film has been edited in such a way that a series of images serving the function of metonymy follow each other very quickly. Such a procedure allows for making the film twice as short and increasing the semantic content of the picture's metaphorical meaning. It also shortens the time of showing drastic images.

"The intellectualism is also exemplified by the procedure of 'suppressing' the attractiveness of certain scenes". ${ }^{2}$ On the other hand, the episodic and fragmentary nature of depicted images points to the emotional dilemmas of the protagonist, it symbolized the train of his thoughts and struggling with not being able to find the answer. The viewer is left wanting more, which feeling is accompanied by distance towards the anachronic character of the narration methods used and, at the same time, by the universal nature of depicted truths about

\footnotetext{
${ }^{10}$ See e.g., Beata Purc-Stępniak, Kula jako symbol vanitas (A sphere as a symbol of vanitas), Gdańsk 2005.

11 Jerzy Płażewski, Laska oświecenia (The grace of enlightenment), "Kino" 1973, no. 11, pp. 12-16.

12 Jerzy Uszyński, Poza dosłownościa (Beyond literalness), in "Kwartalnik Filmowy" 1997, no. 18, p. 99.
} 
the academic community and the dilemmas of young people. The stereotypes are on the one hand disturbing and on the other they confirm what we sense both rationally and intuitively as regards the topic. Jerzy Uszyński seems to be even suggesting that this is a picture of the crisis of culture, of chaos as the natural condition of being, and therefore it is a forecast of something that we are experiencing today more acutely. ${ }^{13}$

Strong visual stimuli, edited like attractions of the Russian avant-gardists, are supplemented with innovative music by Wojciech Kilar with fast rhythm and jarring key. Owing to this, the director encourages the viewer to concentrate harder (what is more, the viewer must also read the captions placed under the depicted pictures). The visual and sound editing is highly innovative, because in addition to laconic and precise presentation of messages subconsciously affecting our perception of other images, it is disturbing and sometimes challenges familiar truths about the human being, for example, a scene depicting a brain surgery performed on a partly anaesthetized patient. At the time of the premiere as well as today such a manner of presentation, i.e., brave and innovative, may give rise to opposition and dislike. But only such feelings make it possible for the director to encourage the viewer to reflection, which is characteristic of both the protagonist of his film as well as himself.

Orde du ratio - the order of science in Zanussi's film - reveals therefore to us only one of the possible meanings of the word "illumination". Physics, biology, mathematics - these are exact sciences that in a way become an embodiment of the idea of the scientific pursuit of truths on the essence of the surrounding reality and the place of the human being in it. Zanussi, who himself studied physics, seems to be saying that such sciences do not give an answer to Franciszek's queries, as they concern something completely different, something that can be neither counted nor measured. In the case of a human being, it is height, weight, eye colour, and the intelligence quotient. In the case of the world, it is measurements, scientific experiments, and results. And the protagonist asks about a different kind of illumination. He is not interested in knowledge resulting from mathematical analysis or a physicist's research, but rather in knowledge of transcendental character. And if so, we are only a step away from the order of art.

\section{Orde du Ars}

"The beginnings of things are thoughts planted by God in the body"14 (St. Bonaventure, 2002).

The order of art is a kind of a mysterious link between the order of the heart and the order of science. This is because of associating this aspect of the film with women: the mother, the lover, and the wife of the main protagonist, and therefore with feelings: family love and sensual love. This aspect of Iluminacja is described more laconically and at first it is hardly noticeable, although — with time - it seems to be the most important. It is very likely that it is a kind of a medium, which on the one hand makes it possible for the protagonist to pass from the order of science to the order of the heart. Such understanding of illumination would be partly associated with the creative inspiration of artists (art references, e.g., presentation of sculptures, etc.) or the clarity of the mind, as experienced by the protagonist during sexual encounters.

The first sphere in which we can talk about the first conscious reference by the director to orde $d u$ ars is a static image of the interiors of the family house of Franciszek Retman. It resembles old salons as depicted in 19th century paintings. The lavishness of forms, shapes, and patterns invokes in the viewer the feeling of

\footnotetext{
13 Ibidem, p. 104.

14 Saint Bonaventure, Journey of the Soul into God-Itinerarium Mentis in Deum, transl. and Introduction by Zachary Hayes, and Philotheus Boehner, OFM, vol. 2, 2002.
} 
completeness, family warmth, and spiritual richness. Quite quickly do we notice that there is a painterly reference in the form of the painting Szal (Frenzy) by Władysław Podkowiński. A naked figure of a woman on a horse points to the house being associated with art, with the mentioned "elitism of the spirit" ascribed to the director himself, but also with feminine sensuality. It therefore foreshadows later encounters of the main protagonist with women.

The main protagonist is associated with the world of science. Closest to life is his wife Małgorzata (Małgorzata Pritulak). His first love — a woman older than him, Agnieszka (Monika Dzienisiewicz-Olbrychska, see Figure 3) - is a link between the world of science and life, between a boy and a woman, between him and erotica. What is interesting, the older woman belongs to both these worlds at the same time. Professionally, she is associated with science, but her relationship with Franciszek is purely emotional.

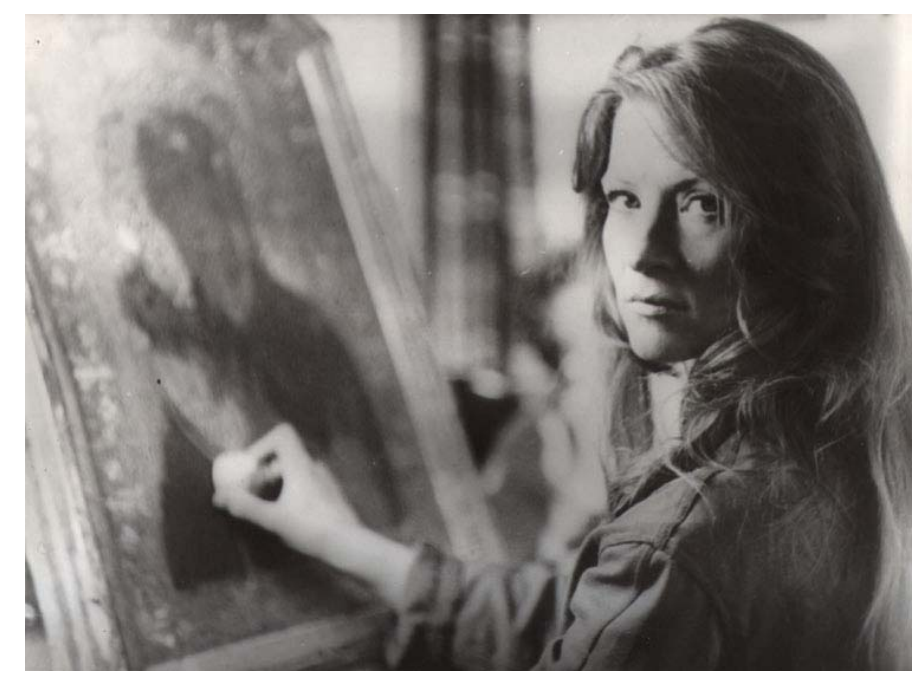

Figure 3. A photo from Iluminacja, directed by Krzysztof Zanussi.

Agnieszka fascinates the young boy with her education, eloquence, social life, and looks. Zanussi presented this relationship in a snapshot-like manner: only suggesting the time when they met, the fascination of the boy with the woman, their first awkward encounter, a night together, some socializing, a fight, and their final break-up. We are guessing that the boy was much more involved in the relationship than the woman. This is supported, for example, by his being overprotective and not being able to forget about her (the scene depicting Franciszek standing in the rain).

The character can also be conventionally associated with art in at least several ways. In the few scenes with the woman we find out that she is interested in art. It is evidenced by her work on the renovation of a painting depicting Virgin Mary and Infant Jesus. Another very significant element is a painterly reference, a collective sculpture, resembling a scene from an educational film on art, soon after their sexual encounter. ${ }^{15}$ The form of introducing this picture into the film substance is significant. On the one hand, it is a metonymy of the physical act of love, fulfilment, which we do not see in the film, it refers therefore to the order of the heart (emotions) or life (sensuality). On the other hand, the manner of presenting this image resembles other references placed in the film, e.g., from anatomy atlases or biographic entries of renowned scientists, which in

\footnotetext{
${ }^{15}$ Art imitates life. It is therefore its reflection. It uses for the purpose scientific achievements: sculpture, painting renovation. Sculpture as an art discipline is most associated with physical effort (biological component) and technical capabilities (sculptor's skills and technique).
} 
turn clearly integrates such presentation with the realm of science. The paradox therefore consists in the fact that the director decides to tell about elusive emotions in a manner which is both lofty and trivial. In this case the loftiness would be associated with using the artistic presentation: a couple of lovers in a subtle gesture of kissing a woman's hand. The triviality would be associated with the scientific, clearly lecture-like presentation of this image, which suggests the shallowness of this interpretation in the context of the physical act of love, which he is trying to replace or simply hide.

A similar procedure was applied by the director when the protagonist has sex with another woman, this time a young student, Małgorzata, with whom he ultimately decides to have a long-lasting relationship. This time, however, a kiss expressing admiration placed on a woman's hand was replaced with an image of a passionate kiss on the lips. This time the sculpture image brings the viewer closer to real closeness and sensuality, which is established between the protagonists.

We are dealing with the realm of art, or rather with the realm of unusual synergy of the matter and spirit, when Franciszek's dream is being examined (it primarily concerns the visualisation of his dream) and when the main protagonist meets with monks. In the first case, we are witnesses to a brief oneiric scene, which is clearly different from other sequences in the film and is more reminiscent of the style of creative documentaries by Wojciech Wiszniewski rather than the meticulous approach to the film substance by Krzysztof Zanussi. The scene represents the anxieties of the protagonist: the feeling of being confined in an enclosed space of a courtyard, a threat - a woman running from a man with an axe in his hand, and finally deformative capabilities of the human mind - metamorphosis of a child held by a woman into a dog. The visionary, illogical, and grotesque character of the scenes makes it possible to include them in the order of science, as they allow for a psychoanalytical approach. They represent a state of being confined and powerless, in which the protagonist finds himself when he has to take care of his newly set up family. On the other hand, the images are associated with art through the creative capabilities of the human mind, which are used primarily by artists. The unreal nature of the images is primarily associated with an artistic, visionary film, referring to surrealism, rather than with the scientific interpretation we were subjected to earlier.

Of similar character is a scene in which we see a fish in an aquarium in unnatural close-up. The space is definitely too small for it. The fish is nervously trying to get some air and cannot move at all. This image represents more forcefully the protagonist being stuck in life, which he clearly does not like. Both images are accompanied by disturbing music, which perfectly suits the nervous and chaotic movements of the camera. The main idea of the director is therefore changeability and experimentalism.

In the order of art (orde $d u$ ars), illumination may be associated with artistic inspiration, spiritual enlightenment, but also with medieval illuminated manuscripts. This association brings us to the story of Franciszek meeting with the monks, where he tries to find answers to his queries. In the film, the director placed a short conversation between the boy and a monk, who talks about a contemplative and ascetic life and the reasons for choosing it. Then there follows a series of visionary scenes in which the protagonist is witness to a funeral of one of the monks. At this point we immediately recall the inscription placed on the grave in Struktura krysztatu: "I was—who you are. I am—who you will be. Remember about me, so that someone will remember about you". ${ }^{16}$

\footnotetext{
${ }^{16}$ Aleksander Ledóchowski wrote about Zanussi's Iluminacja as a contemporary morality play. He links his interpretation primarily with religious considerations, which are exemplified by the appearance of Faustic elements (initiation, science) and
} 
Crypts with mummified bodies of the clergymen bring to mind a medieval play and its love of presenting the art of beautify dying (ars amandi) or the fascination with the vanitas concept. In this way, Zanussi managed to make a reference to the concept of beauty in the Middle Ages, about which for example Umberto Eco wrote in his book Beauty and Art in the Middle Ages. Symmetry, as the fundamental concept affecting the imagination of people from the time, was reflected by a clearly dichotomous division of this plot into: a real, contemplative and dark one, and an unreal, active, and luminous one. It brings to mind the reflections of St. Bonaventure, who combined the theory of abstraction and the theory of illumination, and therefore the views of Aristotle and St. Augustine. He identified knowledge with empirical perception and then with its abstract expression. Moreover, he claimed that we know the essence of things through the "eternal reasons"-in rationibus aeternis. He differentiates six degrees of knowledge, which correspond to six degrees of seeing:

visio intelligentiae per naturam iditae - seeing of the natural mind;

visio intelligentiae per fidem sublevatae — seeing of the mind elated by faith;

visio intelligentiae per Scripturam eruditae - seeing of the mind instructed by the Scriptures;

visio intelligentiae per contemplationem suspensae - seeing of the mind inspired by contemplation;

visio intelligentiae per prophetiam illustratae - seeing of the mind enlightened by prophesy;

visio intelligentiae per raptum absorptae - seeing of the mind absorbed in rapture.

According to St. Bonaventure, knowing things is a three-stage process: via purgativa (liberating the soul from the evil), via illuminativa (internal illumination of the soul), and via unitiva (unity with God). What is interesting, according to the thinker, issues related to morality lie in the sphere of art (ars). The light metaphor, on the other hand, serves the purpose of explaining the mysteries of the nature of the matter. Moreover, light is in every body, is its form. A pure mind acts similarly to the light: "The beginnings of things are thoughts planted by God in the body". In this way, the matter, and thus also the body, has been spiritualized. And it is art that has the power of uniting which is biological (scientific) with that which is spiritual. ${ }^{17}$

\section{Orde du Coeur}

"To souls it is death to become water, to water death to become earth" (Kahn, 1979).

The order of the heart is clearly associated with spiritual enlightenment, which requires the purity of the heart. This type of illumination is discussed by Władysław Tatarkiewicz. The philosopher refers to Confessions by St. Augustine. It is worth associating this order also with Thoughts by Blaise Pascal, in which the author identifies spiritual enlightenment (which is almost of divine character) with love. Blaise was a thinker known for not believing in the power of the reason. It seemed to him that, despite the efforts, he constantly lives in ignorance. If therefore the reason (and thus racta ratio - the operation of the reason) cannot give us knowledge, then maybe faith or love can? Thinking and contemplation, in this context, are the only certain things and they are naturally linked with Franciszek's search for truth about the human being among the monks.

At this point it is worth focussing on identifying the "illumination" from the title with love, the order of the heart and the order of life. In the context of the film, Barbara Mruklik wrote about people expressing

Dantean elements (a journey in search of the truth about the human being and the meaning of life). See Aleksander Ledóchowski, Iluminacja (Illumination), "Kino" 1973, no. 5, pp. 8-13.

17 This was extraordinarily expressed also by Franciszek Starowieyski in a poster for that film. 
themselves through ties with corporeality ${ }^{18}$. By the same token, the researcher suggests that Franciszek is closest to the knowledge not at the university, the hospital or when he is among the monks, but in interpersonal contacts, primarily the ones based on friendship: a trip to the mountains, the death of a friend, and love: meeting Małgorzata, the wedding, and fatherhood. In this context enlightenment is not dressed in laudatory paeans to scientific wisdom or innovation. Neither is it a melancholy descent into the corners of the human psyche (a dream) or soul (a prayer). It becomes a joyous waiting for the birth of the child, playing with the family in a meadow, or maybe a moment of reflection by the river? Is it not so that it is love that opens up our eyes?

Simplicity and calmness combine this order with the realm of thoughts (spirit) and art (artistry). It brings to mind the already analyzed association with the older woman, her interest in magic (fortune-telling and astronomy) and the more down-to-earth relationship with Małgorzta (see Figure 4). Abstract (book) knowledge and irrational (magical) knowledge are replaced by knowledge that is empirical (family) and sensual (sensual love).

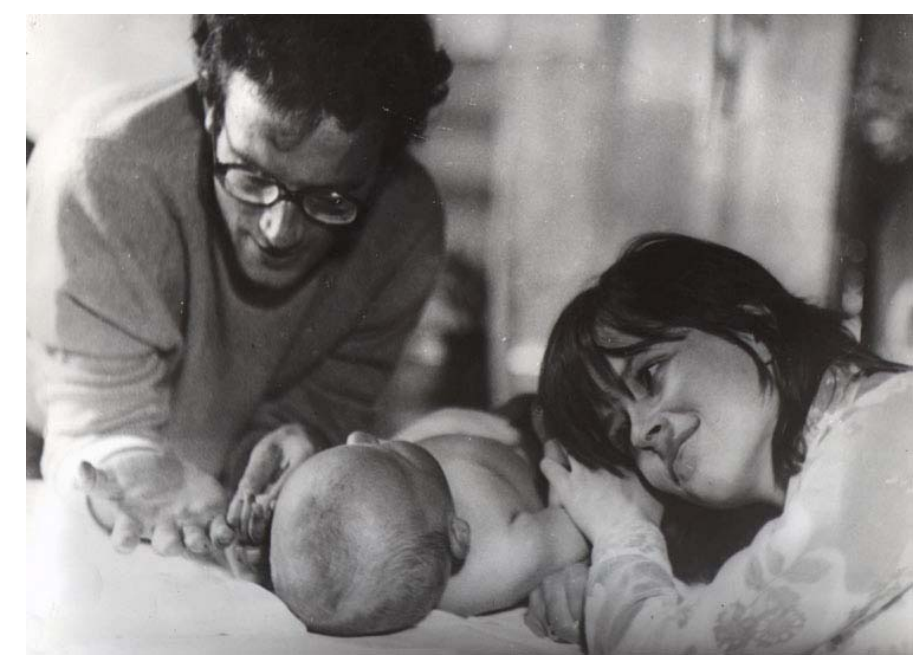

Figure 4 A photo from Iluminacja, directed by Krzysztof Zanussi.

\section{Conclusion}

In Iluminacja, Zanussi poses the fundamental question about the limitations and criteria of getting to know the essence of things and determination which of the types of knowing aspires to be the real one. The choice of exact sciences as the most "certain" ones, paradoxically, makes us realize the naivety resulting from the young age of the main protagonist. Only the real effort of "being in the world" sheds light on this orientation point. There is a collage-like juxtaposition of the two perspectives. This heterogeneity gives rise to ambiguity, which manifests itself in the final scene and echoes in the question: Does the protagonist of Zanussi's film experience illumination in the film or does he, wanting it, come closer to a conviction that we are not as important as we think we are? - as his first love claimed. The question is left hanging in the air. On the one hand, the flow of a river, departing birds that Franciszek is watching, are clearly associated with the idea of Heraclitus of Ephesus

18 Barbara Mruklik, Nasze przedpremiery "Iluminacja” (Our world premieres “Iluminacja”), "Kino” 1973, no. 11. 
that "everything flows", that is everything is passing, it bounces off like waves of the high and low tide. ${ }^{19}$ On the other hand, by way of a clear reference in this scene to the first image: the main protagonist in briefs, standing against a dark background - it may refer to this constant state of invariability, which we experience throughout the whole life. "Everything flows", means that everything is changing, but it is changing next to us, and not within us, so everything is invariable.

\section{References}

Blaise, P. (1953). Thoughts. (T. Żeleński (Boy), Trans.). Warszawa: “St. Wojciech” and "Green Owl”.

Bonaventure, St. (2002). Journey of the Soul into God-Itinerarium Mentis in Deum. (Z. Hayes \& P. Boehner, Trans.). OFM, 2.

Ciarka, R. (1997). Wiedza, wiara i nadzieja (Knowledge, faith and hope). In "Kwartalnik Filmowy" ("Film Quarterly"). Warsaw: The Polish Academy of Sciences.

Goethe, J. W. (2001). Faust. (J. Paszkowski, Trans.). Warszawa: "KWE".

Ledóchowski, A. (1973). Iluminacja (Illumination). "Cinema”, Foundation CINEMA, 5, 8-13.

Mann, T. (1982). The magic mountain. (J. Kramsztyk, Trans.). Warszawa: "Reader".

Mruklik, B. (1973). Nasze przedpremiery "Iluminacja” (Our world premieres "Iluminacja”). "Cinema”, Fundation CINEMA, 11. Płażewski, J. (1973). Laska oświecenia (The grace of enlightenment). "Cinema”, Fundation CINEMA, 11, 12-16.

Purc-Stępniak, B. (2005). Kula jako symbol vanitas (A sphere as a symbol of vanitas). Gdańsk: "Word-Picture-Territories".

St. Augustine. (2008). Confessions. (Z. Kubiak, Trans.). Kraków: "Sign”.

Uszyński, J. (1997). Poza dostownościq (Beyond literalness). In "Kwartalnik Filmowy" ("Film Quarterly"). Warsaw: The Polish Academy of Sciences.

Zanussi, K. (1973). Iluminacja (Illumination) and Eksplikacja (Explication). "Cinema”, Foundation CINEMA, 5, 25-30.

Kahn, C. H. (1979). The Art and Thought of Heraclitus. An Edition of the Fragments with Translation and Commentary. Cambridge: Cambridge University Press.

\section{Filmography}

Iluminacja (1973)

Directed by Krzysztof Zanussi

Screenplay by Krzysztof Zanussi

Director of photography: Edward Kłosiński

Editing: Urszula Śliwińska

Music: Wojciech Kilar

Cast: Stanisław Latało (Franciszek Retman), Monika Dzienisiewicz-Olbrychska (Agnieszka), Małgorzata Pritulak (Małgosia), Jan Skotnicki (the ill man), Edward Żebrowski (the doctor), Włodzimierz Zonn (the dean).

\footnotetext{
${ }^{19}$ Heraclitus imagined the reality in the form of a river. "To souls it is death to become water, to water death to become earth". Change is the only thing that is certain, as higher-order harmony is not visible to people. The philosopher even claimed that we exist and we do not at the same time.
} 